\section{Photoperiod, Chilling, and Light Quality during Daylight Extension Affect Growth and Flowering of Tissue-cultured Easter Lily Plants}

\author{
E. Jay Holcomb ${ }^{1}$ and Robert Berghage \\ Department of Horticulture, The Pennsylvania State University, University \\ Park, PA 16802-4200
}

Additional index words. Lilium longiflorum, leaf number, time to flower, flower number

\begin{abstract}
Easter lily plants (Lilium longiflorum Thunb.), derived from tissue culture and grown continuously, were subjected to various photoperiod and chilling treatments. Lilies grown with daylength extended either with high-intensity discharge (HID) or incandescent lights flowered in the same number of days, but had more flower buds with HID lamps. Flowering was delayed and plants produced more leaves as photoperiod was reduced from 16 to 12 hours. The numbers of leaves, primary, secondary, and tertiary flowers, and the time to flower were all significantly reduced as the duration of extended lighting was increased from 0 to 6 weeks. As the number of weeks of cooling at $5{ }^{\circ} \mathrm{C}$ increased from 0 to 5 , time to flower was significantly reduced.
\end{abstract}

Easter lilies, which are typically grown from bulbs, remain an important crop for many greenhouse producers despite recent declines in production (U.S. Dept. of Agriculture, 1998). Perhaps more than with any other crop, Easter lilies must flower at the proper time, as the sales window is typically $<2$ weeks. Research with temperature and photoperiod with bulbgrown lilies has suggested that long days can either partially replace cold temperature treatment or reduce time to flower when adequate cooling is provided (Gill and Stuart, 1967; Waters and Wilkins, 1967; Weiler and Langhans, 1968).

De Hertogh and Wilkins (1971) reported that 6 weeks of cooling of Easter lily bulbs reduced the number of flowers produced, accelerated flowering of the crop, and reduced both variability in time to flower and plant height. Dole and Wilkins (1994) reported that Easter lily bulbs needed at least 3 weeks of cooling in order to respond to long days (LD). They concluded that 3 weeks of cooling plus 3 weeks of LD produced as rapid flowering as did 6 weeks of cooling. The concept of cooling of lilies has been extended with the use of cool temperature units (CTU), which Tammen et al. (1996) defined as $\left(21^{\circ} \mathrm{C}-\mathrm{t}_{1}\right) \times \mathrm{h}$. Thus, $20^{\circ} \mathrm{C}$ for $24 \mathrm{~h}$ would equal $24 \mathrm{CTU}$, or $1 \mathrm{~h}$ at $4{ }^{\circ} \mathrm{C}$ would equal $17 \mathrm{CTU}$.

Oglevee and Tammen (1986) patented a process for growing Easter lilies from bulblet to flowering plant in 48 weeks. Tammen et al. (1986) described the system and indicated that

Received for publication 4 Oct. 1999. Accepted for publication 20 June 2000. The cost of publishing this paper was defrayed in part by the payment of page charges. Under postal regulations, this paper therefore must be hereby marked advertisement solely to indicate this fact.

${ }^{1}$ To whom requests for reprints should be addressed. E-mail address: ejh3@psu.edu once the plant was large enough, it could initiate flowers on long days. Wickremesinhe et al. (1994) reported that flowering could be induced in Easter lily plants that had been propagated by callus culture in much the same way that Tammen et al. (1986) had done in plants from bulblets. The objective of this research was to determine how plants that had been produced through tissue culture would respond to photoperiod and cooling.

\section{Material and Methods}

Expt. 1. Tissue-cultured plants (150) arrived potted in $15-\mathrm{cm}$ pots ( $1800 \mathrm{~mL}$ volume) from a commercial propagator (Oglevee, Connellsville, Pa.) in mid-Oct. 1997 and were placed in a greenhouse and grown under natural photoperiod to continue accumulation of CTUs. By 15 Dec. 1997, the plants had accumulated $\approx 4000$ CTUs in the greenhouse (plus any CTU accumulated before arrival). Lighting treatments were begun on $15 \mathrm{Dec}$. and ended on 19 Jan. 1998 (Table 1). Incandescent lights extended the day to $16 \mathrm{~h}$ by being turned on at $1600 \mathrm{HR}$ and off at $2300 \mathrm{HR}$ with an irradiance of $\approx 2.2 \mu \mathrm{mol} \cdot \mathrm{s}^{-1} \cdot \mathrm{m}^{-2}$. The HID lights were on for $16 \mathrm{~h}$, being turned on at $800 \mathrm{HR}$ and off at $2400 \mathrm{HR}$ with an irradiance level of 250-350 $\mu \mathrm{mol} \cdot \mathrm{s}^{-1} \cdot \mathrm{m}^{-2}$, unless the outside irradiance level was above $350 \mu \mathrm{mol} \cdot \mathrm{s}^{-1} \cdot \mathrm{m}^{-2}$. On sunny days, the HID lights were off until sunset, then they were turned on to extend the day to $16 \mathrm{~h}$. After the light treatment, plants were returned to natural (short) days, which initially were $10 \mathrm{~h} 40 \mathrm{~min}$, but increased during the experiment to $15 \mathrm{~h}$. The temperature setpoint in the greenhouse was $18^{\circ} \mathrm{C}$. There were 30 plants in each lighting treatment. All lighting treatments were applied in the same greenhouse except for the HID treatment, for which an adjacent greenhouse with the same temperature setpoints was used. The plants were fertilized daily with $250 \mathrm{mg} \cdot \mathrm{L}^{-1} \mathrm{~N}$ from $20 \mathrm{~N}-4.5 \mathrm{P}-16.6 \mathrm{~K}$ fertilizer.

When the first flower bud opened on each plant, height, number of leaves, and number of flower buds were recorded. Flowering date was estimated for plants that were very slow to flower, based on published bud stick measurements. The height was recorded on the date of estimation.

Expt. 2. Plantlets (140) from the same propagator (Oglevee) that were grown in Bradenton, Fla., were received and planted in $1800-\mathrm{mL}$ pots on 6 Nov. and grown at $20^{\circ} \mathrm{C}$. Shortly after planting, all the foliage died, but gradually new leaves emerged. The plants remained under natural days (photoperiod $\approx 10 \mathrm{~h}$ ) until lighting treatments began on 15 Jan. The lighting treatments $(0,1,2,3,4,5$, and 6 weeks of LD) were created by moving the plants under incandescent lighting to extend the daylength to $16 \mathrm{~h}$. After the specified light treatment, plants were returned to natural (initially short) photoperiods. Other cultural practices were as described for Expt. 1. When the first flower bud opened, height, number of leaves, and number of flower buds were recorded.

Expt. 3. Plantlets (120) were received and planted in 1800-mL pots on 6 Nov., and grown in the greenhouse at $20^{\circ} \mathrm{C}$. On 16 Dec., plants were moved to a lighted (10 $\mu \mathrm{mol} \cdot \mathrm{s}^{-1} \cdot \mathrm{m}^{-2}$ ) $5{ }^{\circ} \mathrm{C}$ cooler where they remained from 0 to 5 weeks. Upon removal from the cooler, plants were moved to a greenhouse section with day and night setpoints of $18{ }^{\circ} \mathrm{C}$ and HID lights $(\approx 250$ $\mu \mathrm{mol} \cdot \mathrm{s}^{-1} \cdot \mathrm{m}^{-2}$ ) for $16 \mathrm{~h} \cdot \mathrm{d}^{-1}$.

When the first flower opened, height, number of leaves, and number of flower buds were recorded. Flowering date was for plants that were very slow to flower based on published bud stick measurements.

Statistical analysis. Data were analyzed by analysis of variance (ANOVA) and the significance of treatment effects was determined by regression analysis.

\section{Results and Discussion}

Expt. 1. On 16-h photoperiods, supplemental HID lamps were more effective than incandescent lamps in increasing leaf and flower numbers (Table 1). Light source did not influence the time of flowering; plants flowered in $101 \mathrm{~d}$ under both lighting regimes. However, plants had more leaves and flowers under HID than under incandescent lamps, but were slightly, but not significantly, shorter. Since HID lamps deliver higher photosynthetic photon flux $(P P F)$ than did incandescent lamps, the difference in plant quality is probably related to enhanced photosynthetic activity.

Fourteen hours of incandescent lighting did not promote flowering as effectively as did $16 \mathrm{~h}$, as plants took $9 \mathrm{~d}$ longer to flower (Table 1); however, they had significantly more leaves, were taller, and had somewhat more flowers.

Plants grown with $12 \mathrm{~h}$ of incandescent extended lighting took $20 \mathrm{~d}$ longer to flower than did those on 14-h photoperiods, and prob- 
ably flowered as rapidly as they did only because all the plants were grown under natural and lengthening photoperiods. The plants also produced more tertiary flower buds than did those grown under $14 \mathrm{~h}$.

The length of the photoperiod in the spring increases $\approx 1-2$ min per day from January to March in central Pennsylvania. Photoperiod reaches $15 \mathrm{~h}$ by late-April; thus flowers can be initiated regardless of lighting treatment. The increase in height and leaf number as photoperiod decreased supports the conclusion that flower initiation was delayed by shorter photoperiods. Incandescent lighting generally increases height, but the opposite effect observed here further supports the delay in flowering with short photoperiods. We have no explanation for the increase in tertiary flower buds, but conditions needed for flower initiation may have lasted longer, thus more flowers were initiated.

Expt. 2. The numbers of leaves, primary and secondary flowers, and tertiary flowers, and the time to flower all decreased as duration of supplemental lighting increased (Table 2 ). Both the linear and the quadratic components for each factor were significant, but the overall predictive power of the equations was rather poor (Table 2). Both number of side shoots and height increased with duration of lighting, but again the predictive power of the equations was weak (Table 2). Flowering

Table 1. Effects of photoperiod and light source on flowering and vegetative growth of tissue-cultured Easter lily plants. Expt. 1

\begin{tabular}{|c|c|c|c|c|c|c|c|}
\hline \multirow{3}{*}{$\begin{array}{l}\text { Supplemental } \\
\text { light }\left(h \cdot \mathrm{d}^{-1}\right)\end{array}$} & \multicolumn{4}{|c|}{ No. of: } & \multirow{3}{*}{$\begin{array}{l}\text { Plant height } \\
\text { (cm) }\end{array}$} & \multirow{3}{*}{$\begin{array}{l}\text { Flowering } \\
\text { date (1998) }\end{array}$} & \multirow{3}{*}{$\begin{array}{l}\text { Time to } \\
\text { flower }(\mathrm{d})\end{array}$} \\
\hline & \multirow[b]{2}{*}{ Leaves } & \multirow{2}{*}{$\begin{array}{c}\text { Side } \\
\text { shoots }\end{array}$} & \multicolumn{2}{|c|}{ Flowers } & & & \\
\hline & & & $1^{\circ}+2^{\circ}$ & $3^{\circ}$ & & & \\
\hline HID 16 & 124 & 0.20 & 6.0 & 3.9 & 57.2 & 26 Mar. & 101 \\
\hline Incandescent 16 & 109 & 0.14 & 5.4 & 0.7 & 59.6 & 26 Mar. & 101 \\
\hline 14 & 128 & 0.04 & 5.8 & 0.9 & 70.6 & 4 Apr. & 110 \\
\hline 12 & 168 & 0.07 & 6.0 & 8.1 & 77.2 & 24 Apr. & 130 \\
\hline 10 & 176 & 0.14 & 6.0 & 9.9 & $--^{z}$ & 2 May & 138 \\
\hline F test & $* *$ & NS & $* *$ & $* *$ & $* *$ & --- & $* *$ \\
\hline $\mathrm{LSD}_{0.05}$ & 10.6 & & 0.2 & 1.1 & 11.0 & --- & 3 \\
\hline \multicolumn{8}{|c|}{ Regression (incandescent light only) } \\
\hline \multicolumn{8}{|l|}{ No. of: } \\
\hline Leaves & $\mathrm{L}^{\mathrm{y}}$ & \multirow{2}{*}{\multicolumn{4}{|c|}{$\mathrm{y}=301.6-12.0 \mathrm{x}, R^{2}=0.454^{*}$}} & & \\
\hline Side Shoots & NS & & & & & & \\
\hline Primary flowers & $\mathrm{L}$ & \multicolumn{4}{|c|}{$\mathrm{y}=7.1-0.1 \mathrm{x}, R^{2}=0.12^{*}$} & & \\
\hline \multirow{3}{*}{ Height } & $\mathrm{L}$ & \multicolumn{4}{|c|}{$\mathrm{y}=27.6-1.8 \mathrm{x}, R^{2}=0.59^{*}$} & & \\
\hline & $\mathrm{L}$ & \multirow{2}{*}{\multicolumn{4}{|c|}{$\mathrm{y}=-207+43.9 \mathrm{x}-1.7 \mathrm{x}^{2}, R^{2}=0.22^{*}$}} & & \\
\hline & Q & & & & & & \\
\hline Days to flower & $\mathrm{L}$ & \multicolumn{4}{|c|}{$\mathrm{y}=205.3-6.6 \mathrm{x}, R^{2}=0.79^{*}$} & & \\
\hline
\end{tabular}

${ }^{2}$ Plants were harvested early, thus height was not recorded.

${ }^{{ }^{2}} \mathrm{~L}=$ linear, $\mathrm{Q}=$ quadratic.

ss, *, ${ }^{* *}$ Nonsignificant or significant at $P \leq 0.05$ or 0.01 .

Table 2. The effect of duration (in weeks) of a 16-h photoperiod (extension by incandescent lighting) on the growth and flowering of tissue-cultured Easter lilies grown from Florida plantlets. Expt. 2

\begin{tabular}{|c|c|c|c|c|c|c|c|}
\hline \multirow{3}{*}{$\begin{array}{l}\text { Time in } \\
\text { long days (wk) }\end{array}$} & \multicolumn{4}{|c|}{ No. of: } & \multirow{3}{*}{$\begin{array}{l}\text { Plant height } \\
(\mathrm{cm})\end{array}$} & \multirow{3}{*}{$\begin{array}{l}\text { Flowering } \\
\text { date (1998) }\end{array}$} & \multirow{3}{*}{$\begin{array}{r}\text { Time to } \\
\text { flower (d) }\end{array}$} \\
\hline & \multirow[b]{2}{*}{ Leaves } & \multirow{2}{*}{$\begin{array}{l}\text { Side } \\
\text { shoots }\end{array}$} & \multicolumn{2}{|c|}{ Flowers } & & & \\
\hline & & & $1^{\circ}+2^{\circ}$ & $3^{\circ}$ & & & \\
\hline$\overline{0}$ & 108 & 0.5 & 6.9 & 4.3 & 42.6 & 10 May & 115 \\
\hline 1 & 69 & 0.7 & 5.2 & 1.2 & 33.3 & 26 Apr. & 101 \\
\hline 2 & 73 & 0.6 & 5.5 & 2.2 & 37.7 & 23 Apr. & 98 \\
\hline 3 & 67 & 0.8 & 5.3 & 1.4 & 35.1 & 20 Apr. & 95 \\
\hline 4 & 58 & 1.4 & 4.6 & 0.6 & 39.8 & 17 Apr. & 92 \\
\hline 5 & 66 & 1.2 & 5.0 & 0.8 & 50.4 & 18 Apr. & 93 \\
\hline 6 & 64 & 1.2 & 5.0 & 0.8 & 52.1 & 18 Apr. & 93 \\
\hline Significance & $* *$ & $*$ & $* *$ & $* *$ & $* *$ & --- & $* *$ \\
\hline $\mathrm{LSD}_{0.05}$ & 8.02 & 0.44 & 0.7 & 0.88 & 3.2 & --- & 3.1 \\
\hline
\end{tabular}

No. of:

$\begin{array}{lll}\text { Leaves } & \mathrm{L}^{\mathrm{z}} & \mathrm{y}=89.2-5.5 \mathrm{x}, R^{2}=0.22^{* *} \\ & \mathrm{Q} & \mathrm{y}=100.9-19.6 \mathrm{x}+2.35 \mathrm{x}^{2}, R^{2}=0.35^{* *} \\ \text { Side shoots } & \mathrm{L} & \mathrm{y}=0.5+0.14 \mathrm{x}, \mathrm{R}^{2}=0.08^{* *} \\ & \mathrm{Q} & \mathrm{y}=0.45=0.2 \mathrm{x}-0.01 \mathrm{x}^{2}, R^{2}=0.08^{* *} \\ \text { Primary flowers } & \mathrm{L} & \mathrm{y}=6.12-0.24 \mathrm{x}, \mathrm{R}^{2}=0.09^{* *} \\ & \mathrm{Q} & \mathrm{y}=6.6-0.82 \mathrm{x}+0.09 \mathrm{x}^{2}, R^{2}=0.12^{* *} \\ \text { Tertiary flowers } & \mathrm{L} & \mathrm{y}=2.99-0.45 \mathrm{x}, R^{2}=0.16^{* *} \\ & \mathrm{Q} & \mathrm{y}=3.69-1.29 \mathrm{x}+0.01 \mathrm{x}^{2}, R^{2}=0.20^{* *} \\ \text { Plant height } & \mathrm{L} & \mathrm{y}=34.68+2.3 \mathrm{x}, R^{2}=0.22^{* *} \\ & \mathrm{Q} & \mathrm{y}=40.65-4.9 \mathrm{x}+1.2 \mathrm{x}^{2}, R^{2}=0.40^{* *} \\ \text { Days to flower } & \mathrm{L} & \mathrm{y}=107.8-3.05 \mathrm{x}, R^{2}=0.37^{* *} \\ & \mathrm{Q} & \mathrm{y}=113.07-9.37 \mathrm{x}+1.05 \mathrm{x}^{2}, R^{2}=0.50^{* *}\end{array}$

${ }^{2} \mathrm{~L}=$ linear, $\mathrm{Q}=$ quadratic.

${ }^{*, * *}$ Significant at $P \leq 0.05$ or 0.01 . was most rapid when plants were lighted for $3,4,5$, or 6 weeks; however, the time to flower was significantly longer with 2 than with 3-6 weeks (Table 2). Flowering occurred 2 weeks later in plants not lighted than in those given a single week of light. Weiler and Langhans (1968) concluded that photoperiod could substitute for cooling in bulbpropagated lilies, and our data suggest that this is true for the tissue-cultured lily as well. Flowering was most rapid with 3 weeks of lighting.

Plants were shortest when given 1 week of light, but their height did not differ significantly from that of plants grown with 4 weeks of light. The tallest plants were obtained with 5 or 6 weeks of lighting. Waters and Wilkins (1967) observed a similar effect on Easter lilies from bulbs. Incandescent lamps are high in far-red light, which stimulates stem elongation; thus, the longer the plants were lighted, the taller they became.

Plants that received no lighting had significantly more flowers than did lighted plants; however, all lighted plants had similar numbers of flowers. Waters and Wilkins (1967) observed a similar effect on Easter lilies from bulbs. Unlighted plants produced significantly more leaves than lighted ones, and all lighted plants had similar numbers of leaves. Our data show the same trend. Plants with large numbers of leaves generally have more flowers than do plants with fewer leaves. This was true in Expt. 2 as well. Note that there were a very large number of side shoots that emerged from the media near the primary shoot, particularly on those plants lighted the longest. Unlighted plants probably did not initiate flowers as early, thus, grew vegetatively longer than those that were lighted. We have no explanation for the large number of side shoots.

Expt. 3. The numbers of leaves, side shoots, and flowers, and the height were not affected by the number of weeks the plants were cooled at $5{ }^{\circ} \mathrm{C}$ (data not presented). Plants with no cooling flowered in $94 \mathrm{~d}$, but only 80 $\mathrm{d}$ were required following 4 weeks of cooling (Table 3). Dole and Wilkins (1994) and Roh and Wilkins (1977) reported that time to flower, number of leaves, and number of

Table 3. The effects of duration (in weeks) of cooling on flowering of tissue-cultured Easter lilies grown from Florida plantlets. Expt. 3

\begin{tabular}{|c|c|c|}
\hline $\begin{array}{l}\text { Cooling } \\
\text { (wk) }\end{array}$ & $\begin{array}{c}\text { Flowering } \\
\text { date (1998) }\end{array}$ & $\begin{array}{l}\text { Days to } \\
\text { flower }\end{array}$ \\
\hline 0 & 20 Mar. & 94 \\
\hline 1 & 26 Mar. & 92 \\
\hline 2 & 26 Mar. & 85 \\
\hline 3 & 31 Mar. & 83 \\
\hline 4 & 5 Apr. & 80 \\
\hline 5 & 12 Apr. & 81 \\
\hline Significance & --- & $*$ \\
\hline $\mathrm{LSD}_{0.05}$ & --- & 1.0 \\
\hline \multicolumn{3}{|c|}{ Regression } \\
\hline Days to flower & $\begin{array}{ll}\mathrm{L}^{\mathrm{z}} & \mathrm{y}=93.8-2.9 \\
\mathrm{Q} & \mathrm{y}=95.5- \\
& R^{2}=0.82^{*}\end{array}$ & $\begin{array}{l}0.77^{*} \\
0.52 \mathrm{x}^{2},\end{array}$ \\
\hline
\end{tabular}

${ }^{2} \mathrm{~L}=$ linear, $\mathrm{Q}=$ quadratic

"Significant at $P \leq 0.05$ or 0.01 . 
flowers were affected by duration of cooling, but height was not.

Roh and Wilkins (1977) forced at $16^{\circ} \mathrm{C}$, so the plants received some cold temperature at night. Our forcing temperature was $18^{\circ} \mathrm{C}$, so some cooling may have been provided resulting in flowering of all plants. Although additional cooling reduces the number of flower buds on lilies grown from bulbs, our data show that this is not the case with lilies grown from tissue-cultured plantlets. Additional time in a cooler for Florida-grown plants will not affect the finished quality of a flowering Easter lily.

\section{Literature Cited}

De Hertogh, A. and H.F. Wilkins. 1971. The forcing of northwest-grown Ace and Nellie White Easter lilies. Flor. Rev. 149(3857):29-31.
Dole, J.M. and H. F. Wilkins. 1994. Interaction of bulb vernalization and shoot photoperiod on 'Nellie White' Easter lily. HortScience 29:143145.

Gill, D.L. and N.W. Stuart. 1967. Photoperiod forcing of lilies studied by U.S. Department of Agriculture. Florist and Nursery Exchange, 28 Oct. 1967, p. 10, 11, 33.

Oglevee, J.R. and J.F. Tammen. 1986. Lily processes. U.S. Patent No. 4,570,379.

Roh, S.M. and H.F. Wilkins. 1977. The effects of bulb vernalization and shoot photoperiod treatments on growth and flowering of Lilium longiflorum Thunb. cv. Nellie White. J. Amer. Soc. Hort. Sci. 102:229-235.

Tammen, J.F., T.A. Nell, J.E. Barrett, R. Leonard, F.W. Zettler, and D.S. Wampler. 1996. Studies on the commercial production of pathogenindexed Asiatic lilies in the United States. Acta Hort. 430(1):189-197.
Tammen, J.F., J.R. Oglevee, E.J. Oglevee, and L. Duffy. 1986. A new process for producing pathogen-free Easter lilies. Grower Talks 50(3):62, 65-66.

U.S. Dept. of Agriculture. 1998. Floriculture crops 1998 summary, p. 40-41. Agr. Stat. Board NASS, U.S. Dept. Agr.

Waters, W.E. and H.F. Wilkins. 1967. Influence of intensity, duration, date of light on growth and flowering of uncooled Easter lily (Lilium longiflorum Thunb. 'Georgia'). Proc. Amer. Soc. Hort Sci. 90:433-439.

Weiler, T.C. and R.W. Langhans. 1968. Effect of photoperiod on the vernalization requirement of Lilium longiflorum (Thunb.) cv. Ace. Proc. Amer. Soc. Hort Sci 93:630-639.

Wickremesinhe, E.R.M., E.J. Holcomb, and R.N. Arteca. 1994. A practical method for the production of flowering Easter lilies from callus cultures. Scientia Hort. 60:143-152. 